\title{
KEEFEKTIFAN MODEL DIRECT INSTRUCTION UNTUK MENINGKATKAN KOMPETENSI GURU DALAM MENGAPLIKASIKAN METODE PENGAJARAN BAHASA DI SD
}

\author{
Kuswari $^{1}$, Dina Mardiana ${ }^{2)}$, Simpun $^{3)}$, dan Sapriline ${ }^{4}$ \\ 1,2,3,4 Fakultas Keguruan dan Ilmu Pendidikan, Universitas Palangka Raya \\ 1email: hajikuswari.56@gmail.com \\ 2email: dina_mardiana@fkip.upr.ac.id \\ 3email: simpunmpd@gmail.com \\ 4email: saprilinefkip@gmail.com
}

\begin{abstract}
This study aims to analyze the effectiveness of the use of the direct instruction (DI) learning model in improving the competence of classroom teachers in SD Muhammadiyah Pahandut Palangka Raya by applying language teaching method in the design of Integrated Thematic Lesson Plan for Indonesian Language Learning Focus. Eleven class teachers at SD Muhammadiyah Pahandut were selected as the sample of this research using a purposive sampling technique which was taken from the total population. This research used a quantitative method using an experimental design named one group pretest-posttest design. From the results of the analysis of two related sample statistical test, it can be concluded that the result of this study showed the DI learning model is effective to improve the competence of elementary school teachers in applying the language teaching method.
\end{abstract}

Keywords: direct instruction models, teacher, primary school, language teaching methods

Abstrak: Penelitian ini bertujuan untuk menganalisis keefektifan penggunaan model pembelajaran direct instruction (DI) dalam meningkatkan kompetensi guru kelas di SD Muhammadiyah Pahandut dengan mengaplikasikan metode pengajaran bahasa pada rancangan RPP Tematik Terpadu Fokus Pembelajaran Bahasa Indonesia. Sebelas orang guru kelas di SD Muhammadiyah Pahandut Palangkaraya sebagai sampelnya yang dipilih dengan teknik purposive sampling dari jumlah populasinya. Penelitian ini menggunakan metode kuantitatif dengan model desain eksperimen one group pretest-posttest design. Dari hasil analisis uji statistik dua sampel berkorelasi (two related sample), dapat disimpulkan hasil penelitian ini bahwa model pembelajaran DI efektif untuk meningkatkan kompetensi guru sekolah dasar dalam mengaplikasikan metode pengajaran bahasa.

Kata kunci: model direct instruction, guru, sekolah dasar, metode pengajaran bahasa

\section{PENDAHULUAN}

Kurikulum 2013 (K13) dalam pelaksanaan pendidikan dan pengajaran di Indonesia, serta merta membuat para guru harus belajar kembali tentang berbagai konsep rancangan perangkat pembelajaran yang termuat di dalamnya. Pada dasarnya, K13 ini merupakan aplikasi lebih lanjut dari kurikulum sebelumnya seperti KBK dan KTSP Tahun 2006, yakni sama-sama berorientasi pada suatu capaian kompetensi dasar peserta didik. Namun, K13 lebih bertujuan untuk menghasilkan insan Indonesia yang produktif, inovatif dan kreatif melalui penguatan pengetahuan, sikap, dan keterampilan secara utuh dan terpadu (Ismawati 2015).

Kemampuan mengaplikasikan strategi pengajaran bahasa dalam pembelajaran Bahasa Indonesia di sekolah dasar (SD) merupakan salah satu kompetensi pedagogik yang harus dimiliki guru kelas. Kompetensi pedagogik tersebut diperoleh seorang guru kelas secara utuh dan 
terpadu dengan tiga kompetensi lainnya yaitu kompetensi profesional, sosial, dan kepribadian pada saat mengenyam pendidikan di tingkat strata satu (S1). Guru kelas yang memiliki empat kompetensi tersebut hendaknya mampu melaksanakan program pendidikan sesuai rancangan dalam desain K13. Namun, tak dapat dipungkiri masih banyak guru kelas yang belum mampu melaksanakannya. Hal ini berdampak terhadap pencapaian tujuan pembelajaran di SD, peserta didik tidak mendapatkan pembelajaran dengan baik dan hasil belajarnya pun kurang baik. Situasi tersebut semakin parah jika kualifikasi akademik guru kelas berlatar belakang disiplin ilmu bukan dari pendidikan dasar yang harus menguasai minimal lima mata pelajaran wajib dan pembelajaran terpadu di SD.

Menurut Awliyah dkk (2021), bahasa menjadi faktor penting dan harus dikuasai oleh manusia. Oleh karena pentingnya hal itu, salah satunya bahasa digunakan sebagai bahasa pengantar dalam pendidikan dan hendaknya kecakapan berbahasa dipelajari sejak usia sekolah dasar. Apabila telah fasih dalam menguasi bahasa maka seorang anak tidak akan mengalami kesulitan dalam mendapatkan pesan penting, informasi, dan ungkapan yang diucapkan guru dalam kegiatan pembelajaran di kelas.

Berdasarkan hasil kajian awal yang telah dilakukan tim peneliti di SD Muhammadiyah Pahandut Kota Palangkaraya, diperoleh temuan tentang permasalahan kurangnya kemampuan para guru kelas dalam hal mengaplikasikan metode pengajaran bahasa untuk fokus pembelajaran Bahasa Indonesia. Permasalahan tersebut pun ditambah dengan belum mampunya para guru kelas mengaplikasikan konsep pembelajaran yang sesuai dengan Kurikulum 2013, seperti ditemukannya berbagai istilah baru yang masih cukup "asing" bagi mereka pada Silabus Mata Pelajaran Bahasa Indonesia Tahun 2016. Hal tersebut semakin rumit ketika para guru kelas di SD Muhammadiyah Pahandut harus mengaplikasikan strategi pengajaran bahasa Indonesia ke dalam rancangan strategi pembelajaran tematik terpadu di sekolah dasar yang menggunakan pendekatan saintifik. Salah satu faktor penyebabnya adalah tidak adanya informasi akurat yang diterima oleh sebagian besar guru kelas berkenaan dengan implementasi K13 itu, seperti belum pernah menerima pelatihan tentang K13.

Berkenaan dengan permasalahan tersebut mengakibatkan guru kelas hanya mengaplikasikan jenis metode pembelajaran secara umum, bukan jenis metode pengajaran khusus untuk fokus pembelajaran bahasa Indonesia yang merupakan salah satu bagian terpenting dalam strategi pengajaran bahasa. Padahal, menurut Tarigan (2011), metode pengajaran bahasa beroirentasi pada keterampilan maupun proses yang menginginkan agar siswa dapat membaca, berbicara, memahami, menerjemahkan dan mengenali penerapan-penerapan pembelajaran bahasa dan sastra yang dipelajari. Oleh karena itu, penggunaan metode belajar bahasa harus sesuai dengan struktur nilai dan kegiatankegiatan dalam urutan belajar bahasa. Jadi, metode apapun yang digunakan dalam pengajaran bahasa, jelas bahwa tujuan utamanya agar para siswa terampil atau mampu berbahasa, bukan terampil dalam bidang di luar bahasa, sehingga diperlukan metode pengajaran yang khusus dalam aplikasi pembelajarannya.

Pembelajaran Bahasa dan Sastra Indonesia, merupakan satu dari lima mata pelajaran wajib yang harus dipelajari di sekolah dasar. Oleh karena itu, guru kelas di SD hendaknya memiliki kompetensi untuk mampu mengaplikasikan berbagai strategi pengajaran bahasa yang di antaranya mencakupi metode, pendekatan, dan teknik pembelajaran bahasa yang mendidik secara kreatif terkait dengan mata pelajaran Bahasa Indonesia di SD/MI (Permendiknas Nomor 16 Tahun Nomor 16 Tahun 2007). Penggunaan teknik, strategi, metode dan model yang digunakan oleh guru dalam proses pembelajaran saat ini semakin bermacam-macam variasinya di dunia pendidikan. Demikian pula untuk pembelajaran keterampilan berbahasa 
seperti pembelajaran menyimak, berbicara, membaca, dan menulis. Dalam sebuah model pembelajaran terdapat sintagmatik yang dijadikan sebagai acuan dalam proses pembelajaran (Puspasari dan Setyaningsih 2020).

Menurut Brown (2007), banyak variabel penting yang mempengaruhi proses pembelajaran bahasa kedua seseorang, demikian pula dengan peserta didik usia sekolah dasar. Seorang guru kelas di SD sangatlah penting memiliki kemampuan untuk memahami beberapa variabel tersebut, karena merupakan faktor-faktor utama yang mempengaruhi prinsip-prinsip pengajaran dan pembelajaran bahasa. Variabel yang pertama adalah karakteristik pembelajar, kemudian ada faktor linguistik, proses pembelajaran, usia dan pemerolehan, variabel instruksional, konteks, dan tujuan pembelajaran. Di dalam proses pembelajaran tersebutlah pentingnya seorang guru bahasa memiliki kompetensi yang baik dalam mengaplikasikan metode pengajaran bahasa yang tepat untuk masingmasing materi pembelajaran bahasa.

$\begin{array}{ccc}\text { Metode } & \text { pengajaran bahasa } \\ \text { merupakan cara guru dalam }\end{array}$

mengimplementasikan tingkatan-tingkatan prioritas dalam strategi pembelajaran bahasa sebagai sesuatu yang utuh dan terpadu yang disusun oleh seorang guru untuk merencanakan pengajarannya yang mencakupi silabus, pendekatan, gaya guru, teknik pembelajaran, dan bahan materi pengajaran. Ada sepuluh metode utama pengajaran bahasa yang dirumuskan oleh Tarigan, yaitu: (1) Metode terjemahan tata bahasa; (2) Metode langsung; (3) Metode audiolingual; (4) Metode endekatan kognitif; (5) Metode pendekatan ganda; (6) Metode responsi fisik total; (7) Metode alami; (8) Metode belajar bahasa masyarakat; (9) Metode cara diam; dan (10) Metode sugestopedia (2011: 246-247).

Berdasarkan permasalahan yang dihadapi oleh para guru kelas di SD Muhammadiyah Pahandut ini, tim peneliti menyimpulkan perlunya memberikan sebuah treatment untuk mengatasi hal tersebut. Treatment dalam sebuah kegiatan penelitian eksperimen dengan teknik pelatihan intensif tentang strategi pengajaran bahasa yang mencakupi sepuluh metode utama pengajaran bahasa. Hal ini sebagai solusi yang diberikan kepada guru kelas di SD Muhammadiyah Pahandut untuk meningkatkan kompetensinya dalam mengaplikasikan metode pengajaran bahasa pada rancangan RPP Tematik Terpadu Fokus Pembelajaran Bahasa Indonesia. Treatment tersebut dilakukan dengan menggunakan pendekatan model pembelajaran direct instruction (DI).

Model pembelajaran direct instruction (DI) merupakan model pembelajaran langsung yang dikenal dengan sebutan active teaching atau gaya wholeclass teaching yang mengacu pada gaya mengajar guru yang terlibat aktif dalam mengusung isi pelajaran kepada peserta didik dan mengajarkan secara langsung kepada seluruh kelas (Suprijono, 2009). Proses pembelajaran bahasa memerlukan komunikasi dua arah yang efektif. Demikian pula untuk pola pembelajaran dalam kelas pelatihan penggunaan metode pengajaran bahasa yang dilaksanakan peneliti terhadap guru kelas di SD Muhammadiyah Pahandut ini. Melalui model DI (direct instruction), tim peneliti dapat berinteraksi dengan melakukan tanya jawab dan pendampingan secara maksimal kepada para guru kelas.

Salah satu teori pendukung model pembelajaran DI (direct instruction) adalah teori behaviorisme yang menekankan belajar sebagai perubahan perilaku, bahwa belajar sebagai proses stimulus-respons yang bersifat mekanis (Bagus dan Mardiana 2018). Modelling adalah pendekatan utama dalam model pembelajaran DI (direct instruction) ini. Modelling berarti mendemonstrasikan suatu prosedur kepada peserta didik. Dalam hal ini, peneliti yang bertindak sebagai modelling, atau sebagai narasumber dalam kegiatan pelatihan tersebut.

Modelling yang dilaksanakan dalam kegiatan pelatihan penggunan metode pengajaran bahasa tersebut mengikuti uruturutan berikut: (1) Tim peneliti mendemonstrasikan perilaku yang hendak dicapai sebagai hasil belajar, yaitu memberikan pendalaman materi tentang sepuluh metode pengajaran bahasa; (2) Perilaku itu dikaitkan dengan perilaku- 
perilaku lain yang sudah dimiliki pembelajar, yaitu mengaplikasikannya ke dalam rancangan perangkat pembelajaran tematik terpadu; (3) Tim peneliti mendemonstrasikan langkah-langkah dalam menentukan metode pengajaran untuk salah satu materi pembelajaran bahasa dan mnejelaskan langkah-langkah aplikasinya dengan cara yang jelas, terstruktur, dan berurutan disertai penjelasan mengenai apa yang dikerjakannya setelah setiap langkah selesai dikerjakan; dan (4) Pembelajar, dalam hal ini guru kelas, perlu mengingat langkah-langkah yang dilihatnya dan kemudian menirukannya, ini dilakukan saat mengaplikasikannya ke dalam RPP Tematik Terpadu.

Model DI (direct instruction) merupakan model pembelajaran yang dirancang khusus untuk menunjang proses belajar siswa berkaitan dengan pengetahuan deklaratif dan prosedural yang terstruktur dengan baik yang dapat diajarkan dengan pola kegiatan bertahap, selangkah demi selangkah. Model pembelajaran ini meliputi training model, active model, active teaching model, mastery teaching, explicit instruction (Sintia, dkk 2018). Selanjutnya, Sintia, dkk mendeskripsikan tentang Penerapan Model Direct Instruction Papa Saya untuk Meningkatkan Keterampilan Proses Sains Siswa Kelas IV di SD 2 Panjunan Tema 7. Tim riset ini menerapkan model DI berbantuan permainan papa saya karena model ini sesuai untuk diterapkan pada siswa di sekolah dasar. Fokus pembelajaran yang menjadi objek penelitian ini adalah IPA dan Bahasa Indonesia di sekolah dasar.

Purwanti dan Supriyono (2018) mengemukakan kelebihan dari model pembelajaran DI (direct instruction) di antaranya adalah menggunakan metode ceramah sekaligus demonstrasi yang memudahkan pembelajar untuk memahami materi yang disampaikan, mendemonstrasikan dua pengetahuan tahap demi tahap yaitu keterampilan prosedural dan deklaratif. Oleh karena itu, model ini memang tepat digunakan untuk mengajarkan atau melatihkan suatu keterampilan berbahasa, seperti keterampilan menulis deskripsi bagi siswa di sekolah dasar.

Berdasarkan kajian yang dilakukan dari beberapa penelitian terdahulu tersebut, dapat disimpulkan bahwa penelitian tentang keefektifan model pembelajaran DI (direct instruction) untuk meningkatkan kompetensi guru sekolah dasar dalam mengaplikasikan metode pengajaran bahasa belum pernah dilakukan. Mengingat pentingnya hal itu, penelitian tentang keefektifan model pembelajaran DI (direct instruction) untuk meningkatkan kompetensi strategi pengajaran bahasa guru sekolah dasar dalam mengaplikasikan metode pengajaran bahasa ini menarik dan perlu dilakukan.

Hasil kajian awal yang dilakukan tim peneliti terhadap kemampuan guru kelas dalam mengaplikasikan metode pengajaran bahasa hanya menunjukkan rata-rata 63 dengan kategori cukup baik. Observasi ini dilakukan melalui analisis dokumen perangkat RPP Tematik Terpadu Fokus Pembelajaran Bahasa Indonesia yang dirancang oleh guru kelas di SD Muhammadiyah Pahandut. Oleh karena itu, sebuah solusi yang ditawarkan tim peneliti untuk mengatasi permasalahan tersebut yaitu "Keefektifan Model Direct Instruction untuk Meningkatkan Kompetensi Guru dalam Mengaplikasikan Metode Pengajaran Bahasa di SD".

Tujuan dilaksanakannya penelitian ini adalah: (1) untuk menganalisis kompetensi guru kelas di SD Muhammadiyah Pahandut dalam mengaplikasikan metode pengajaran bahasa pada rancangan RPP Tematik Terpadu Fokus Pembelajaran Bahasa Indonesia sebelum dilatih dengan menggunakan model pembelajaran DI (direct instruction), (2) untuk menganalisis kompetensi guru kelas di SD Muhammadiyah Pahandut dalam mengaplikasikan metode pengajaran bahasa pada rancangan RPP Tematik Terpadu Fokus Pembelajaran Bahasa Indonesia sesudah dilatih dengan menggunakan model pembelajaran DI (direct instruction), dan (3) untuk mendeskripsikan keefektifan penggunaan model pembelajaran DI (direct instruction) dalam meningkatkan kompetensi guru kelas di SD 
Muhammadiyah Pahandut mengaplikasikan metode pengajaran bahasa pada rancangan RPP Tematik Terpadu Fokus Pembelajaran Bahasa Indonesia.

Berdasarkan pada tujuan yang ingin dicapai dalam pelaksanaan penelitian ini, secara teoretis diharapkan hasilnya dapat memberi manfaat pada khazanah kepustakaan pengajaran bahasa, khususnya pengajaran bahasa Indonesia yang ada keterkaitannya dengan pendidikan di sekolah dasar. Secara praktis, diharapkan hasil penelitian ini dapat bermanfaat bagi para guru bahasa, khususnya guru kelas yang mengajarkan bahasa Indonesia di sekolah dasar, dalam rangka meningkatkan kompetensinya mengaplikasikan metode pengajaran bahasa yang tepat pada setiap materi pembelajaran bahasa Indonesia.

\section{METODE PENELITIAN}

Pelaksanaan penelitian ini menggunakan metode kuantitatif dengan model desain eksperimen one group pretestposttest design (Sugiyono 2014). Eksperimen dilakukan dengan membandingkan hasil observasi terhadap kemampuan guru. Observasi pertama dilakukan dengan memberikan pretest terhadap kemampuan guru dalam menggunakan metode pengajaran bahasa sebelum $\left(\mathrm{O}_{1}\right)$ dilatih dengan model pembelajaran DI. Selanjutnya, observasi kedua dilakukan dengan memberikan posttest terhadap kemampuan guru dalam menggunakan metode pengajaran bahasa sesudah $\left(\mathrm{O}_{2}\right)$ dilatih dengan model pembelajaran DI (direct instruction).

Populasi penelitian ini adalah guru kelas di SD Muhammadiyah Pahandut. Pengambilan sampel dilakukan dengan menggunakan teknik purposive sampling, karena subjek penelitian diambil berdasarkan tujuan tertentu, yakni memilih sekelompok subjek berdasarkan karakteristik tertentu yang dinilai memiliki keterkaitan dengan ciri-ciri atau karakteristik dari populasi yang akan diteliti.
Adapun yang menjadi sampel penelitian ini adalah sebanyak sebelas orang guru kelas yang diambil dari keseluruhan populasi. Variabel bebas dalam penelitian ini adalah model pembelajaran direct instruction, dan yang menjadi variabel terikatnya adalah kemampuan menggunakan metode pengajaran bahasa.

Instrumen yang digunakan untuk mengumpulkan data hasil penelitian berupa Lembar Penugasan Kemampuan Guru Mengaplikasikan Metode Pengajaran Bahasa dalam Rancangan RPP Tematik Terpadu Fokus Pembelajaran Bahasa Indonesia dan Lembar Penilaian Kemampuan Guru Mengaplikasikan Metode Pengajaran Bahasa dalam Rancangan RPP Tematik Terpadu sebelum dan sesudah dilatih dengan menggunakan model pembelajaran DI (direct instruction). Instrumen ini berupa lembar penilaian perangkat evaluasi pengajaran yang mengandung unsur metode pengajaran bahasa dalam komponen penilaiannya.

Teknik pengumpulan data yang digunakan dalam penelitian ini adalah teknik tes, pretest-posttest. Pretest dilakukan terhadap kemampuan guru mengaplikasikan metode pengajaran bahasa sebelum (pretest) dilatih dengan menggunakan model pembelajaran DI (direct instruction). Selanjutnya, posttest dilakukan terhadap kemampuan guru mengaplikasikan metode pengajaran bahasa sesudah (posttest) dilatih dengan menggunakan model pembelajaran DI (direct instruction).

Standar penilaian terhadap kemampuan guru mengaplikasikan metode pengajaran bahasa sebelum dan sesudah (pretest-posttest) dilatih dengan menggunakan model pembelajaran DI (direct instruction) mengacu pada Alat Penilaian Kinerja Guru (APKG) dengan rentang skor $0-55=$ kurang baik; 56-69= cukup baik; 70-79 = baik; $80-100=$ sangat baik. Selanjutnya, nilai masing-masing kemampuan guru pada kedua data tersebut dianalisis dengan menggunakan uji statistik dua sampel berhubungan (two related sample) untuk mencari taraf signifikannya. Uji statistik yang dipakai adalah uji non- 
parametrik Wilcoxon mengingat jumlah sampel terbatas $(\mathrm{N}<30)$ dengan asumsi data tidak terdistribusi normal.

\section{HASIL DAN PEMBAHASAN}

Hasil pretest yang dilakukan terhadap kompetensi guru kelas di SD Muhammadiyah Pahandut dalam mengaplikasikan metode pengajaran bahasa pada rancangan RPP Tematik Terpadu Fokus Pembelajaran Bahasa Indonesia sebelum diberi treatment dalam bentuk pelatihan intensif dengan menggunakan model pembelajaran DI (direct instruction) menunjukkan rata-rata $X_{1}=60,91$, dengan kategori cukup baik. Selanjutnya, posttest diberikan kepada guru kelas di SD Muhammadiyah Pahandut sesudah diberi treatment dalam bentuk pelatihan intensif dengan menggunakan model pembelajaran DI (direct instruction). Pelatihan intensif itu dilaksanakan dalam dua tahap dengan alokasi waktu pelaksanaan selama dua hari.

Tahap pertama pelatihan dilaksanakan dengan memberikan pendalaman materi tentang teori sepuluh metode utama pengajaran bahasa. Untuk tahap yang kedua, pelatihan intensif dilaksanakan dengan memberikan pendampingan kepada para guru kelas untuk mengaplikasikan metode pengajaran bahasa pada rancangan RPP Tematik Terpadu Fokus Pembelajaran Bahasa Indonesia.

Setelah diberikan treatment dengan menggunakan model pembelajaran DI (direct instruction) dalam sebuah kelas pelatihan intensif penggunaan metode pengajaran bahasa, para guru kelas diberikan tes. Tes dilakukan dalam bentuk penugasan menyusun rancangan perangkat pembelajaran RPP Tematik Terpadu Fokus Pembelajaran Bahasa Indonesia yang memuat salah satu metode pengajaran bahasa dalam strategi pembelajarannya untuk masing-masing kelas yang diampunya. Dari hasil posttest ini nilai ratarata guru kelas sudah menunjukkan hasil berkategorik baik, yaitu dengan perolehan nilai rata-rata $X_{2}=75,45$. Untuk lebih jelas, berikut deskripsi nilai per individu dari hasil pretest dan posttest tersebut.

Tabel 1. Data Nilai Pretest dan Posttest Kemampuan Guru Kelas (N=11)

\begin{tabular}{llll}
\hline No & $\begin{array}{c}\text { Sampel (N)/ Guru } \\
\text { Kelas }\end{array}$ & $\begin{array}{c}\text { Nilai Pretest } \\
\left(\mathbf{X}_{\mathbf{1}}\right)\end{array}$ & $\begin{array}{c}\text { Nilai Posttest } \\
\left(\mathbf{X}_{2}\right)\end{array}$ \\
\hline 1. & 001 & 60 & 75 \\
2. & 002 & 60 & 75 \\
3. & 003 & 65 & 80 \\
4. & 004 & 60 & 75 \\
5. & 005 & 60 & 75 \\
6. & 006 & 60 & 80 \\
7. & 007 & 60 & 75 \\
8. & 008 & 60 & 70 \\
9. & 009 & 60 & 70 \\
10. & 010 & 65 & 85 \\
11. & 011 & 60 & 70 \\
& Jumlah & $\mathbf{8 1 0}$ & $\mathbf{8 3 0}$ \\
\hline & Nilai rata-rata/ mean & $\mathbf{X}_{\mathbf{1}}=\mathbf{6 0 , 9 1}$ & $\mathbf{X}_{\mathbf{2}}=\mathbf{7 5 , 4 5}$ \\
\hline
\end{tabular}

Selanjutnya, nilai masing-masing kemampuan guru pada kedua data tersebut dianalisis dengan menggunakan uji statistik
Wilcoxon untuk mencari taraf signifikansinya. 
Table 2. Analisis Data terhadap Nilai Pretest dan Posttest Kemampuan Guru Kelas

\begin{tabular}{|c|c|c|c|c|c|c|}
\hline & & $\mathbf{N}$ & $\begin{array}{r}\text { Mean } \\
\text { rank }\end{array}$ & $\begin{array}{r}\text { Sum of } \\
\text { rank }\end{array}$ & $\mathbf{Z}$ & $\begin{array}{l}\text { Asymp. } \\
\text { Sig. } \\
\text { (2-tailed) }\end{array}$ \\
\hline $\begin{array}{l}\text { Nilai Posttes - } \\
\text { Nilai Pretes }\end{array}$ & $\begin{array}{l}\text { Negative Ranks } \\
\text { Positive Ranks }\end{array}$ & $\begin{array}{r}0^{\mathrm{a}} \\
11^{\mathrm{b}}\end{array}$ & $\begin{array}{r}.00 \\
6.00\end{array}$ & $\begin{array}{r}.00 \\
66.00\end{array}$ & $-2.994^{a}$ & .003 \\
\hline
\end{tabular}

Berdasarkan hasil analisis pada nilai pretest dan posttest kemampuan guru mengaplikasikan metode pengajaran bahasa ke dalam rancangan perangkat Rencana Pelaksanaan Pembelajaran (RPP) Tematik Terpadu Fokus Pembelajaran Bahasa Indonesia diperoleh hasil analisis statistik menunjukkan nilai $\mathrm{p}=0,003$ yang menyatakan $\mathrm{p}<0,05$ sehingga Ho ditolak. Dengan demikian model pembelajaran direct instruction efektif digunakan untuk meningkatkan kompetensi guru sekolah dasar dalam mengaplikasikan penggunaan metode pengajaran bahasa.

Penggunaan model pembelajaran direct instruction (DI) merupakan treatment yang digunakan dalam sebuah kegiatan penelitian dengan model desain eksperimen one group pretest-posttest design. Eksperimen dilakukan melalui kegiatan pelatihan secara intensif terhadap sebelas orang guru kelas di SD Muhammadiyah Pahandut Kota Palangkaraya. Secara khusus, tujuan dilakukannya penelitian ini adalah untuk meningkatkan kompetensi guru kelas di SD Muhammadiyah Pahandut dalam mengaplikasikan metode pengajaran bahasa pada rancangan perangkat RPP Tematik Terpadu Fokus Pembelajaran Bahasa Indonesia melalui model pembelajaran DI (direct instruction).

Namun, sebelum dilatih dengan menggunakan model pembelajaran DI (direct instruction) itu, terlebih dilakukan pretest terhadap kompetensi sebelas orang guru kelas dalam mengaplikasikan metode pengajaran bahasa pada perangkat RPP Tematik Terpadu Fokus Pembelajaran Bahasa Indonesia. Hasil pretest menujukkan nilai rata-rata kemampuan guru kelas hanya mencapai angka 60,91 dengan kategori cukup baik.

Treatment model pembelajaran DI (direct instruction) dalam kegiatan penelitian eksperimen ini dilakukan dalam dua kali pertemuan. Pertemuan pertama pada tahap pendalaman materi, dan pertemuan yang kedua pada tahap pendampingan mengaplikasikan metode pengajaran bahasa rancangan perangkat RPP Tematik Terpadu Fokus Pembelajaran Bahasa Indonesia. Semua tahapan treatment ini dilakukan sesuai dengan langkahlangkah dalam model pembelajaran DI (direct instruction), yakni langkah modelling. Berikut ini penjabarannya.

Pertama, tim peneliti mendemonstrasikan perilaku yang hendak dicapai sebagai hasil belajar, yaitu memberikan pendalaman materi tentang sepuluh metode utama pengajaran bahasa. Pada kegiatan pendalaman materi ini, peneliti berlaku sebagai narasumber dalam kegiatan pelatihan penggunaan metode pengajaran bahasa. Materi pelatihan tersebut disusun peneliti dalam sebuah makalah dengan isi materi sepuluh metode utama pengajaran bahasa tersebut adalah (1) Metode terjemahan tata bahasa; (2) Metode langsung; (3) Metode audiolingual; (4) Metode endekatan kognitif; (5) Metode pendekatan ganda; (6) Metode responsi fisik total; (7) Metode alami; (8) Metode belajar bahasa masyarakat; (9) Metode cara diam; dan (10) Metode sugestopedia. Teknik dalam modelling ini menggunakan teknik ceramah modifikasi, yaitu penyajian materi yang dipadukan dengan kegiatan tanya jawab. Tanya jawab berkenaan dengan permasalahan pengaplikasian metode dalam pembelajaran bahasa pada kelas yang diampu oleh masing-masing guru kelas tersebut.

Kedua, pendalaman materi tentang sepuluh metode utama pengajaran bahasa 
yang telah didemonstrasikan tim peneliti dikaitkan dengan pengalaman dan tindakantindakan lain yang pernah dilaksanakan oleh para guru kelas dan contoh-contoh lain yang relevan. Hal tersebut yaitu beberapa permasalahan pelaksanaan pembelajaran yang berkaitan dengan pengaplikasian metode pengajaran bahasa ke dalam rancangan perangkat RPP tematik terpadu fokus pembelajaran bahasa Indonesia.

Ketiga, tim peneliti mendemonstrasikan atau memberikan contoh langkah-langkah dalam menentukan metode pengajaran untuk salah satu materi pembelajaran bahasa. Peneliti memberikan contoh format penyusunan RPP Tematik Terpadu Fokus Pembelajaran Bahasa Indonesia yang dalam strategi pembelajarannya memuat salah satu metode pengajaran bahasa yang relevan dengan materi pembelajarannya. Tahapan ini dilakukan peneliti dengan menjelaskan langkah-langkah aplikasi memilih metode pengajaran bahasa yang tepat, memuatnya dalam rancangan RPP dan melaksanakannya dalam langkah-langkah kegiatan pembelajaran.

Tahapan tersebut dilanjutkan dalam pelaksanaan treatment hari kedua, yaitu pendampingan mengaplikasikan metode pengajaran bahasa rancangan perangkat RPP Tematik Terpadu Fokus Pembelajaran Bahasa Indonesia. Pada tahapan ini, guru kelas melakukan penugasan menyusun rancangan perangkat RPP tersebut sesuai dengan langkah-langkah yang telah didemostrasikan peneliti dengan cara yang jelas, terstruktur, dan berurutan disertai penjelasan mengenai apa yang harus dikerjakan guru kelas setelah setiap langkah selesai dikerjakan.

Keempat, tahapan ini sudah masuk evaluasi hasil penugasan untuk data nilai posttest. Para guru kelas perlu mengingat langkah-langkah yang dilihatnya dari penyajian materi hingga contoh-contoh yang didemonstrasikan oleh peneliti sebagai narasumber. Hal itu agar guru kelas dapat menirukannya dengan tepat ke dalam rancangan perangkat RPP Tematik Terpadu Fokus Pembelajaran Bahasa Indonesia.

Selanjutnya, hasil tugas guru kelas tersebut dilakukan penilaian guna disajikan sebagai data nilai posttest pada penelitian ini. Dari hasil posttets ini ditemukan data nilai rata-rata guru kelas adalah 75,45 . Uji signifikansi pun dilakukan terhadap nilai pretets dan posttets kemampuan guru kelas tersebut. Dari hasil uji signifikansi Wilcoxon untuk dua data berpasangan tersebut maka diperoleh bahwa nilai $\mathrm{p}<0,05$. sehingga $\mathrm{Ho}$ ditolak. Dengan demikian model pembelajaran direct instruction (DI) efektif digunakan untuk meningkatkan kompetensi guru sekolah dasar dalam mengaplikasikan penggunaan metode pengajaran bahasa.

Sebagaimana hasil penelitian yang dilakukan oleh Bagus dan Mardiana (2018), bahwa pendekatan direct instruction (DI), merupakan model pembelajaran langsung yang mengacu pada gaya mengajar seorang pengajar yang terlibat aktif dalam mengusung isi pelajaran kepada para pembelajarnya dan mengajarkan secara langsung kepada seluruh kelas. Dalam hal ini pengajar berfungsi sebagai model yang efektif yang melakukan demonstrasi atau pemberian contoh tentang konsep materi pelajaran kepada para pembelajarnya.

Pola pembelajaran dalam kelas pelatihan penggunaan metode pengajaran bahasa yang dilaksanakan peneliti terhadap guru kelas di SD Muhammadiyah Pahandut ini merupakan pola yang selaras dalam proses pembelajaran bahasa yang memerlukan komunikasi dua arah yang efektif. Melalui model pembelajaran DI, peneliti dapat menyajikan materi secara langsung, berinteraksi dengan melakukan tanya jawab dan pendampingan secara maksimal kepada para guru kelas.

Modelling adalah pendekatan utama dalam model pembelajaran DI (direct instruction) ini (Suprijono 2009). Modelling berarti mendemonstrasikan suatu prosedur kepada pembelajar, dapat berbentuk penyajian materi beserta contoh-contohnya. Direct instruction selaras dengan direct methode atau metode langsung dalam pengajaran bahasa. Dalam hal ini, pengajar yang bertindak sebagai modelling, memberikan contoh secara langsung kepada para pembelajar. Hal tersebut pula yang telah dilakukan peneliti kepada guru kelas pada saat memberikan treatment tentang penggunaan metode pengajaran bahasa. 
Dengan demikian, berdasarkan hasil penelitian tentang "Keefektifan Model Direct Instruction untuk Meningkatkan Kompetensi Guru dalam Mengaplikasikan Metode Pengajaran Bahasa di SD" ini, dapat disimpulkan bahwa penggunaan model pembelajaran direct instruction sangat efektif untuk meningkatkan kompetensi guru sekolah dasar dalam mengaplikasikan metode pengajaran bahasa. Hal itu ditunjukkan dari perolehan nilai hasil pretest kemampuan guru kelas sebelum diberikan treatment menggunakan model pembelajaran direct instruction hanya ratarata 60,91 dan hanya dua orang guru kelas yang memperoleh nilai tertinggi, yakni 65 . Setelah diberikan treatment menggunakan model pembelajaran direct instruction memperoleh rata-rata 75,45 , dan ada tiga orang guru kelas yang memperoleh nilai di atas 75 , yakni 80 dan 85 .

Dari hasil studi pustaka terhadap beberapa penelitian terdahulu yang relevan, tim peneliti pun memperoleh temuan bahwa penelitian tentang keefektifan model pembelajaran direct instruction untuk meningkatkan kompetensi guru sekolah dasar dalam mengaplikasikan metode pengajaran bahasa belum pernah dilakukan. Jadi, temuan penelitian ini merupakan hal yang baru dalam khazanah kepustakaan penelitian di bidang teaching improvement di sekolah dasar. Oleh karena itu, penelitian tentang keefektifan model pembelajaran direct instruction untuk meningkatkan kompetensi guru sekolah dasar dalam mengaplikasikan metode pengajaran bahasa ini diharapkan dapat memberikan manfaat dan kontribusi bagi para peneliti selanjutnya ingin meneliti permasalahan yang selaras. Demikian pula bagi masyarakat pengguna, pendidikan sekolah dasar, para pendidik di sekolah dasar, harapannya hasil penelitian ini menjadi kontribusi yang relevan dan penting bagi peningkatan kemampuan mengajarkan bahasa di sekolah dasar.

\section{SIMPULAN}

Berdasarkan pembahasan dan hasil analisis data penelitian, simpulan dari pelaksanaan ini adalah: (1) kompetensi guru kelas di SD Muhammadiyah Pahandut dalam mengaplikasikan metode pengajaran bahasa pada rancangan RPP Tematik Terpadu Fokus Pembelajaran Bahasa Indonesia sebelum dilatih dengan menggunakan model pembelajaran direct instruction hanya memperoleh nilai rata-rata 61 dengan kategori cukup baik; (2) kompetensi guru kelas di SD Muhammadiyah Pahandut dalam mengaplikasikan metode pengajaran bahasa pada rancangan RPP Tematik Terpadu Fokus Pembelajaran Bahasa Indonesia sesudah dilatih dengan menggunakan model pembelajaran direct instruction (DI) telah meningkat lebih baik ditunjukkan dengan perolehan nilai rata-rata 75,45 yang berkategori baik; dan (3) model pembelajaran direct instruction (DI) efektif digunakan untuk meningkatkan kompetensi guru kelas di SD Muhammadiyah Pahandut dalam mengaplikasikan metode pengajaran bahasa pada rancangan RPP Tematik Terpadu Fokus Pembelajaran Bahasa Indonesia.

\section{DAFTAR RUJUKAN}

Arikunto, S. (2006). Metodologi Penelitian Pendidikan. Yogyakarta: FIP IKIP.

Awliyah, R. F., Suyadi, Jannah, F. R., dan Mustofa, A. (2021). Aspek Perkembangan Bahasa Anak pada Tingkat Sekolah Dasar. JPE (Jurnal Pendidikan Edutama). 8(1), 99-106. doi http://dx.doi.org/10.30734/jpe.v8i $\underline{1.1045}$

Brown, D. (2007). Principles of Language Learning and Teaching. California: San Fransisco State University.

Bagus, D. dan Mardiana, D. (2018). Pengembangan Model Direct Instruction untuk Meningkatkan 
Kompetensi Mahasiswa dalam Memahami Teori dan Genre Sastra Indonesia. Jurnal Pendidikan IPS, 7(1), 137-150.

Dikti. (2007). Permendiknas Nomor 16 Tahun 2007: Tentang Standar Kualifikasi Akademik dan Kompetensi Guru. Jakarta: Kemendiknas.

Ismawati, E. (2015). Telaah Kurikulum dan Pengembangan Bahan Ajar. Yogyakarta: Penerbit Ombak.

Kemdikbud. (2016). Silabus Mata Pelajaran Bahasa Indonesia SD/MI: Kurikulum 2013. Jakarta: Kemdikbud.

Puspasari, Q. K., dan Setyaningsih N. H. (2020). Keefektifan Model Pembelajaran Picture and Picture dan Model Sugesti Imajinasi dalam Pembelajaran Menulis Puisi pada Siswa Kelas VIII. Jurnal Pendidikan Bahasa dan Sastra Indonesia, 9(1), 19-25.

Doi https://doi.org/10.15294/jpbsi.v9 $\underline{\mathrm{i} 1.27572}$

Purwanti, R. dan Supriyono. (2018). Penerapan Model Pembelajaran Langsung untuk Meningkatkan Keterampilan Menulis Deskripsi bagi Siswa Sekolah Dasar. Jurnal Pendidikan Guru Sekolah Dasar, 6(5), 839-848. Retrieved from https://jurnalmahasiswa.unesa.ac.id/i ndex.php/jurnalpenelitianpgsd/article/view/23818/21 $\underline{765}$

Suprijono, A. (2009). Cooperative Learning: Teori dan Aplikasi PAIKEM. Yogyakarta: Pustaka Pelajar.

Sugiyono. (2014). Metode Penelitian Pendidikan: Pendekatan Kuantitatif, Kualitatif, dan $R \& D$. Bandung: Alfabeta.

Sintia, R. dkk. (2018). Penerapan Model Direct Instruction Papa Saya untuk Meningkatkan Keterampilan Proses Sains Siswa Kelas IV di SD 2 Panjunan Tema 7. Jurnal Prakarsa Paedagogia, 1(1), 101-108. Retieved from http://eprints.umk.ac.id/id/eprint/939 9

Tarigan, H. G. (2011). Pengajaran dan Pemerolehan Bahasa. Bandung: Angkasa. 